\title{
Simple and efficient expression of Agaricus meleagris pyranose dehydrogenase in Pichia pastoris
}

\author{
Christoph Sygmund • Alexander Gutmann • Iris Krondorfer • Magdalena Kujawa • \\ Anton Glieder • Beate Pscheidt • Dietmar Haltrich • Clemens Peterbauer • Roman Kittl
}

Received: 5 August 2011 /Revised: 24 September 2011 / Accepted: 22 October 2011 / Published online: 13 November 2011

(C) The Author(s) 2011. This article is published with open access at Springerlink.com

\begin{abstract}
Pyranose dehydrogenase (PDH) is a fungal flavin-dependent sugar oxidoreductase that is highly interesting for applications in organic synthesis or electrochemistry. The low expression levels of the filamentous fungus Agaricus meleagris as well as the demand for engineered PDH make heterologous expression necessary. Recently, Aspergillus species were described to efficiently secrete recombinant $\mathrm{PDH}$. Here, we evaluate recombinant protein production with expression hosts more suitable for genetic engineering. Expression in Escherichia coli resulted in no soluble or active PDH. Heterologous expression in the methylotrophic yeast Pichia pastoris was investigated using two different signal sequences as well as a codon-optimized sequence. A 96-well plate activity screening for transformants of all constructs was established and the best expressing clone was used for large-scale production in 50$\mathrm{L}$ scale, which gave a volumetric yield of $223 \mathrm{mg} \mathrm{L}^{-1} \mathrm{PDH}$ or $1,330 \mathrm{UL}^{-1} \mathrm{~d}^{-1}$ in space-time yield. Purification yielded $13.4 \mathrm{~g}$ of pure enzyme representing $95.8 \%$ of the initial activity. The hyperglycosylated recombinant enzyme had a
\end{abstract}

Electronic supplementary material The online version of this article (doi:10.1007/s00253-011-3667-7) contains supplementary material, which is available to authorized users.

C. Sygmund · I. Krondorfer · M. Kujawa • D. Haltrich •

C. Peterbauer $\cdot$ R. Kittl $(\bowtie)$

Department of Food Sciences and Technology,

University of Natural Resources and Applied Life Sciences

(BOKU), Muthgasse 11,

1190 Vienna, Austria

e-mail: roman.kittl@boku.ac.at

A. Gutmann $\cdot$ M. Kujawa $\cdot$ A. Glieder $\cdot$ B. Pscheidt

Austrian Centre of Industrial Biotechnology (ACIB),

Petersgasse 14,

8010 Graz, Austria
$20 \%$ lower specific activity than the native enzyme; however, the kinetic properties were essentially identical. This study demonstrates the successful expression of PDH in the eukaryotic host organism $P$. pastoris paving the way for protein engineering. Additionally, the feasibility of large-scale production of the enzyme with this expression system together with a simplified purification scheme for easy high-yield purification is shown.

Keywords Pyranose dehydrogenase - Pichia pastoris . Heterologous expression · Agaricus · Large scale Microscale

\section{Introduction}

Pyranose dehydrogenase (PDH; pyranose/acceptor oxidoreductase, EC 1.1.99.29) is a flavin-dependent sugar oxidoreductase (Volc et al. 1997, 2001; Kujawa et al. 2007; Sygmund et al. 2008; Morrison et al. 1999). It is an extracellular, glycosylated enzyme mainly found in a relatively narrow group of litter-decomposing fungi belonging to the Agaricaceae (Volc et al. 2001). The biological role of pyranose dehydrogenase in fungi still remains unclear although the enzyme is thought to participate in lignocellulose degradation. The functions suggested for $\mathrm{PDH}$ are the reduction of quinones or radical intermediates formed during lignocellulose degradation preventing their repolymerization (Ander and Marzullo 1997) as well as the production of Fenton's reagent via reduction of metal ions (Kerem et al. 1999) which may attack cellulose, xylan, and lignin.

Pyranose dehydrogenase catalyzes the oxidation of free, nonphosphorylated sugars and the transfer of resulting electrons to a number of (substituted) quinones and 
complexed metal ions rather than to molecular oxygen. It exhibits extremely broad sugar substrate specificity, while in contrast only a rather limited number of electron acceptors are used by the enzyme. Unlike other sugar oxidoreductases like cellobiose dehydrogenase or pyranose 2-oxidase, which exclusively oxidize sugars at the $\mathrm{C}-1$ and $\mathrm{C}-2$, respectively, $\mathrm{PDH}$ is able to oxidize at $\mathrm{C}-1$ to $\mathrm{C}-4$ with $\mathrm{C}-2$ and/or C-3 predominating, depending on the structure of the sugar (mono-, di-, oligo-saccharide, or glycoside) and the source of the enzyme.

Because of these unique properties, PDH is of interest for a number of technological applications, recently reviewed by Peterbauer and Volc (2010). Among these is the conversion of carbohydrates to interesting products for the food industry, e.g., the conversion of D-galactose to Dtagatose via 2-keto-D-galactose (Giffhorn 2000; Giffhorn et al. 2000). Plain di/tricarbonyl sugars as the main reaction products of PDH could serve as basis for the synthesis of amino sugar moieties of homologues to amino glycoside antibiotics (Reitz and Baxter 1990). The relaxed substrate specificity of PDH makes it an attractive target for further improvements of its reactivity with derivatives of already established substrates such as aromatic glycosides, which may provide new attractive building blocks for synthesis of carbohydrate-based drugs.

A different, very promising application for PDH is its use as anodic biocatalyst in enzymatic biofuel cells, which transform chemical to electrical energy via electrochemical reactions (Barton et al. 2004; Bullen et al. 2006). PDH was successfully "wired" to electrodes using osmium redox polymers and was shown to be suitable for this application (Tasca et al. 2007; Zafar et al. 2010). Apart from being able to provide a second pair of electrons per sugar molecule if double oxidation occurs, PDH's inactivity with molecular oxygen can be considered an advantage. Unlike in biofuel cells, employing glucose oxidase or pyranose oxidase no harmful $\mathrm{H}_{2} \mathrm{O}_{2}$ is being formed as a byproduct, avoiding potential oxidative damage to the enzyme or the redox polymer, thereby prolonging the endurance of the biofuel cell. A possibility to increase the power output of a PDH biofuel cell would be to lower the redox potential of the enzyme. This, as well as increasing the activity of PDH with technologically important substrates, could be targeted by protein engineering.

In the past few years, rational and semirational design approaches have shown to be very useful in improving enzyme properties (Lutz 2010). Crucial for success is expression of site-directed mutants or saturation mutagenesis libraries of the target gene with high yields in a genetically easy to manipulate expression host (bacteria and yeasts).

The gene of PDH1 from Agaricus meleagris was the first identified and isolated PDH-encoding gene (Kittl et al. 2008) and was recently expressed in Aspergillus spp.
(Pisanelli et al. 2010). Hereby, we describe for the first time the successful heterologous expression of a PDH gene in the methylotrophic yeast Pichia pastoris and the scalability of production and purification of the enzyme on larger scale.

\section{Materials and methods}

Chemicals and microorganisms

All chemicals were of the highest purity grade available and were purchased from Sigma (St. Louis, MO, USA) unless stated otherwise. Restriction endonucleases, T4 DNA ligase and DNA-modifying enzymes were obtained from Fermentas unless stated otherwise and were used as recommended by the manufacturer. Nucleic acid amplifications were done employing Phusion High-Fidelity DNA Polymerase (New England Biolabs, Ipswich, MA, USA), dNTP mix, oligonucleotide primers (Invitrogen, Carlsbad, CA, USA), and a GeneAmp PCR System 2700 thermocycler (Applied Biosystems, Foster City, CA, USA). The $p d h 1$ gene coding for pyranose dehydrogenase from the basidiomycete A. meleagris (GenBank accession number AY753307) has been previously isolated and cloned into the pCR Blunt II TOPO vector (Kittl et al. 2008). Escherichia coli strain DH5 $\alpha$-T1 was used for subcloning and BL21 DE3 for expression (Invitrogen). P. pastoris strain CBS 7435 was used for expression. Ferrocenium hexafluorophosphate and the substituted quinones were from Aldrich (Steinheim, Germany). Phenyl-Sepharose Fast Flow resin was purchased from Amersham Pharmacia Biotech (Uppsala, Sweden) while DEAE Sepharose Fast Flow resin was from GE Healthcare (Chafont St. Giles, UK). PNGaseF was purchased from NewEnglandBiolabs.

\section{Construction of a $p d h 1$ expression vector for $E$. coli}

The $p d h 1$ gene from A. meleagris was amplified from the published plasmid pdh1 in pCR Blunt II TOPO vector (Kittl et al. 2008) using the primers 5pdhN-Nde and 3pdhNHind. Nucleotide sequences of all primers used in this work are shown in Table 1. The polymerase chain reaction (PCR) fragment was cut with the restriction enzymes $N d e I$ and HindIII and ligated into the equally treated expression vector pET21a. The resulting plasmid pET21apdh1 was transformed into electrocompetent E. coli BL21 DE3 for expression under control of the $\mathrm{T} 7$ promoter.

Expression of $p d h 1$ in E. coli

E. coli cells carrying the pET21apdh1 plasmid were grown in $\mathrm{TB}$ medium $\left(12 \mathrm{gL}^{-1}\right.$ peptone from casein, $24 \mathrm{gL}^{-1}$ 
Table 1 Oligonucleotide primer sequences (restriction sites are underlined)

\begin{tabular}{ll}
\hline Name & Sequence 5'-3' \\
\hline 5pdhN-Nde & TGCACATATGGCTATCACGTACCAACACC \\
3pdhN-Hind & CGAATAAGCTTAGTATAACTCTTTGC \\
5 pdhN-Asc & TCAAGGCGCGCCCGAAACGATGCTGCCTCGAGTGACC \\
3 pdhN-Not & AGATGCGGCCGCTTAGTTATAACTCTTTGCTATCAACG \\
5 pdhS-Eco & ATTCAAGAATTCCGAACGATG \\
3pdhS-Not & AGATGCGGCCGCTTAATTG \\
5 alpha-Eco & AAAGATTCCGAAACGATGAGATTCCC \\
5 alpha-Asc & AAAGGCGCGCCGAAACGATGAGATTCC \\
3alpha & AGCTTCGGCCTCTCTCTTCTCG \\
5 pdhN-alpha & CGAGAAGAGAGAGGCCGAAGCTGCTATCACGTACCAACACC \\
5 pdhS-alpha & CGAGAAGAGAGAGGCCGAAGCTGCTATCACCTATCAACACC \\
\hline
\end{tabular}

yeast extract and $4 \mathrm{~mL} \mathrm{~L}^{-1}$ glycerol in $100 \mathrm{mM}$ potassium phosphate buffer, $\mathrm{pH} 7.5)$ and induced with two concentrations of IPTG $(0.01,0.10 \mathrm{mM})$ as well as $0.5 \%$ lactose at a $100-\mathrm{mL}$ scale in baffled flasks at $140 \mathrm{rpm}$ and $25^{\circ} \mathrm{C}$ overnight. Ten milliliter of the cultures were centrifuged at $4,000 \times g$ for $10 \mathrm{~min}$ at $4{ }^{\circ} \mathrm{C}$, the cell pellets were resuspended in breaking buffer $(50 \mathrm{mM}$ potassium phosphate buffer pH 6.5 supplemented with $300 \mu \mathrm{M}$ PMSF) and broken using a French press. After ultracentrifugation $\left(30,000 \times g, 30 \mathrm{~min}, 4{ }^{\circ} \mathrm{C}\right)$ the crude extract was tested for enzyme activity and the pellet was analyzed for insoluble PDH. Sodium dodecyl sulfate polyacrylamide gel electrophoresis (SDS-PAGE) was performed on commercial 8$25 \%$ acrylamide gels with silver staining of protein bands. Electrophoresis and the staining procedure were done with the PhastSystem (Pharmacia) according to manufacturer's recommendations.

\section{Codon optimization of $p d h 1$ for expression in $P$. pastoris}

The open reading frame of the $p d h 1$ gene from $A$. meleagris and the Saccharomyces cerevisiae $\alpha$-factor sequence were codon-optimized with the program GeneDesigner from DNA2.0 (https:/www.dna20.com/genedesigner2) employing the high-methanol codon usage of P. pastoris (Abad et al. 2010), which was calculated based on the genes for alcohol oxidase1 (AOX1), DAS, FLD1, and HbHNL using the DOS program GCUA (http://gcua.schoedl.de). Additionally, mRNA 3 '-end processing signals and restriction enzyme recognition sequences (EcoRI, NotI, $B g l \mathrm{II}, S a c \mathrm{I})$ were eliminated. The resulting sequences were checked with the program Leto1.0 from Entelechon (www.entechelon.com) for avoiding strong stem-loop structures of the mRNA that were identified by GeneBee (http://www.genebee.msu.ru/). The synthetic gene was ordered from GenScript Corporation (Piscataway, NJ, USA) with the native leader sequence and the flanking restriction sites EcoRI and NotI. For sequences, see Electronic supplementary material.

\section{Construction of $p d h 1$ expression vectors for $P$. pastoris}

The $p d h 1$ cDNA and the synthetic gene were amplified with the primer pairs $5 \mathrm{pdhN}-\mathrm{Asc} / 3 \mathrm{pdhN}-\mathrm{Not}$ and $5 \mathrm{pdhS}$ Eco/3pdhS-Not, respectively. Both PCR products were digested with the respective restriction enzymes and ligated into the equally treated vector pPpT2 (Abad et al. 2010; Ruth et al. 2010). Replacement of the $\alpha$-factor-derived sequence with that of the native signal sequence was done by overlap extension PCR. To this end, the whole $\alpha$-factor pre-pro leader sequence was amplified with the primers 5alpha-Eco and 3alpha for fusion with the synthetic gene and with 5alphaAsc and 3alpha for fusion with the native gene. These PCR products were finally fused to the corresponding sequences encoding the mature proteins that were amplified with $5 \mathrm{pdhS}$-alpha/3pdhS-Not or $5 \mathrm{pdhN}$ alpha/3pdhN-Not. The resulting PCR products were cut with the respective restriction enzymes and ligated into the equally digested shuttle vector pPpT2. An overview of the constructs is presented in Table 2. After transformation of the constructs into chemically competent $E$. coli DH5 $\alpha-\mathrm{T} 1$ cells, the plasmids were proliferated, linearized with the respective restriction enzymes, and transformed into electrocompetent $P$. pastoris. Electrocompetent Pichia cells were prepared and transformed following the condensed protocol of Lin-Cereghino et al. (2005). For selection, Zeocin was used in a final concentration of $100 \mu \mathrm{g} \mathrm{mL}^{-1}$. The resulting colonies were picked and grown in 96-well deep well plates.

Microscale cultivation in deep well plates

Microscale cultivation and expression in 96-well deep well plates was done according to Weis et al. (2004) with some 
Table 2 Overview of $p d h 1$ constructs used for expression in P. pastoris in deep-well plates

nd Not detectable

\begin{tabular}{lllll}
\hline Construct & Leader & Gene & $\begin{array}{l}\text { Number of screened } \\
\text { transformants }\end{array}$ & $\begin{array}{l}\text { Maximum activity } \\
\left(\mathrm{U} \mathrm{mL}^{-1}\right)\end{array}$ \\
\hline$\alpha$-PDH_nat & $\alpha$-Factor & Native & 176 & nd \\
$n$-PDH_nat & Native & Native & 352 & 0.57 \\
$\alpha$-PDH_syn & $\alpha$-Factor & Synthetic & 84 & nd \\
$n$-PDH_syn & Native & Synthetic & 252 & 0.36 \\
\hline
\end{tabular}

modifications. Cells were grown in $250 \mu \mathrm{L}$ BMD1 $\left(1.34 \%\right.$ yeast nitrogen base, $4 \times 10^{-5} \%$ biotin, $1 \%$ glucose, $200 \mathrm{mM}$ potassium phosphate, $\mathrm{pH} 6.0$ ) at $28{ }^{\circ} \mathrm{C}$, $320 \mathrm{rpm}$, and $80 \%$ humidity for approximately $60 \mathrm{~h}$ to reach the stationary growth phase. BMM2 medium $\left(250 \mu \mathrm{L} ; 1.34 \%\right.$ yeast nitrogen base, $4 \times 10^{-5} \%$ biotin, $1 \%$ methanol, and $200 \mathrm{mM}$ potassium phosphate, $\mathrm{pH} 6.0$ ) was added so that it gave a final concentration of $0.5 \%$ methanol. About 70, 82, and $108 \mathrm{~h}$ after the start of the cultivation, $50 \mu \mathrm{L}$ BMM10 (BMM2 with 5\% methanol) were added to keep up induction. After a total of $130 \mathrm{~h}$, the cultivation was stopped. The deep-well plates were centrifuged at 4,000 rpm and $4{ }^{\circ} \mathrm{C}$ for $10 \mathrm{~min}$ and the supernatants were used for enzyme activity assays in microtiter plates.

Large-scale production of recPDH1 in $P$. pastoris

A fed-batch cultivation was carried out in a 60-L computercontrolled stirred tank reactor (Applikon, Schiedam, The Netherlands) with an initial volume of $40 \mathrm{~L}$ fermentation basal salts medium $\left(21 \mathrm{~mL} \mathrm{~L}{ }^{-1} \mathrm{H}_{3} \mathrm{PO}_{4}(85 \%) ; 0.93 \mathrm{gL}^{-1}\right.$ $\mathrm{CaSO}_{4} \cdot 2 \mathrm{H}_{2} \mathrm{O} ; 14.9 \mathrm{gL}^{-1} \mathrm{MgSO}_{4} \cdot 7 \mathrm{H}_{2} \mathrm{O} ; 18.2 \mathrm{gL}^{-1} \mathrm{~K}_{2} \mathrm{SO}_{4}$; $4.13 \mathrm{gL}^{-1} \mathrm{KOH} ; 4 \%(v / v)$ glycerol) supplemented with $4.35 \mathrm{~mL} \mathrm{~L}^{-1}$ PTM1 trace salts (Invitrogen) and $10 \mathrm{~mL}$ Antifoam 204 (Sigma, St. Louis, MO, USA).

Temperature, dissolved oxygen (DO), and $\mathrm{pH}$ were monitored online by the Bio Controller ADI 1030 (Applikon). Oxygen concentration was regulated to a minimum of $4 \%$ and kept constant by supplying sterilefiltered air and adjusting stirrer velocity. Temperature was set to $30{ }^{\circ} \mathrm{C}$ and the $\mathrm{pH}$ value was regulated to 5 and kept constant by addition of ammonium hydroxide solution. Fifteen 1-L baffled shaking flasks containing $300 \mathrm{~mL}$ YPD-Zeocin medium each $\left(10 \mathrm{gL}^{-1}\right.$ yeast extract, $20 \mathrm{gL}^{-1}$ peptone from casein, $4 \mathrm{gL}^{-1}$ glucose, and $25 \mathrm{mg} \mathrm{L}^{-1}$ Zeocin) were inoculated with $P$. pastoris strain n-PDH_natCC11 and grown overnight at $30{ }^{\circ} \mathrm{C}$ and $150 \mathrm{rpm}$. This preculture was used for inoculation of the fermenter $(10 \% v / v)$.

When the initially added glycerol was consumed completely (indicated by a DO spike after $13.5 \mathrm{~h}$ ), a glycerol feed $(50 \%$ glycerol supplemented with
$12 \mathrm{~mL} \mathrm{~L}^{-1}$ PTM1 trace salts) was started. Recombinant protein production was induced after $40 \mathrm{~h}$ of fermentation by feeding methanol (100\% methanol supplemented with $12 \mathrm{~mL} \mathrm{~L}^{-1}$ PTM1 trace salts). The feed rate was adjusted at constant air flow rate and stirrer speed to a DO of $4 \%$. After $180 \mathrm{~h}$ of cultivation, the fermenter was harvested, cells were separated from the culture medium by centrifugation at $4,000 \times \mathrm{g}, 4{ }^{\circ} \mathrm{C}$ for $10 \mathrm{~min}$ (Sorvall Evolution RC, Kendro Laboratory Products, Newtown, CT, USA) and the supernatant was recovered as a crude enzyme preparation.

Samples of the fermentation broth were taken periodically; wet biomass was determined by centrifugation (Eppendorf Centrifuge 5424, Hamburg, Germany) for $10 \mathrm{~min}$ at $14,000 \times \mathrm{g}$ and weighing of the pellet. $\mathrm{PDH}$ activity was measured with the standard assay and soluble protein concentration was determined according to Bradford.

\section{Purification of recombinant PDH1}

recPDH1 was purified at room temperature by hydrophobic interaction chromatography and anion exchange chromatography. $\left(\mathrm{NH}_{4}\right)_{2} \mathrm{SO}_{4}$ was added to the crude extract to $30 \%$ saturation, clarified by centrifugation and the solution was loaded onto a Phenyl-Sepharose Fast Flow column $\left(8,500 \mathrm{~mL}\right.$; flow rate $\left.330 \mathrm{~mL} \mathrm{~min}{ }^{-1}\right)$ equilibrated with $50 \mathrm{mM}$ phosphate buffer $(\mathrm{pH} 6.5$, $\left.1.5 \mathrm{M}\left(\mathrm{NH}_{4}\right)_{2} \mathrm{SO}_{4}\right)$. After washing the column with 1 column volume $(\mathrm{CV})$ of the same buffer, recPDH1 was eluted with a linear gradient of starting buffer to $50 \mathrm{mM}$ phosphate buffer $(\mathrm{pH}$ 6.5) in $1 \mathrm{CV}$ and fractions were collected.

Fractions with high PDH activity were concentrated and desalted to a conductivity equal to or less than $2 \mathrm{mS} \mathrm{cm} \mathrm{cm}^{-1}$ using cross-flow filtration (Microza ultrafiltration module, Pall Austria Filter GmbH, Vienna, Austria). A pool of the fractions containing highest activity was loaded onto a DEAE Sepharose Fast Flow anion exchange chromatography column $(500 \mathrm{~mL})$ equilibrated with $50 \mathrm{mM}$ Bis Tris buffer ( $\mathrm{pH} \mathrm{6)}$ and washed with $1 \mathrm{CV}$ of this buffer. For elution, a linear salt gradient $(0-1 \mathrm{M} \mathrm{NaCl}$ in $50 \mathrm{mM}$ Bis Tris, $\mathrm{pH}$ 6) was run in $10 \mathrm{CV}$ at $10 \mathrm{~mL} \mathrm{~min}^{-1}$. 
Fractions with the highest activities were pooled, concentrated (Vivaflow 50 module, Sartorius AG, Göttingen, Germany), aliquoted, and stored at $-30{ }^{\circ} \mathrm{C}$.

\section{Enzyme assay}

Pyranose dehydrogenase activity was determined by following spectrophotometrically the D-glucose-dependent reduction of the ferrocenium ion $\left(\mathrm{Fc}^{+}\right)$to ferrocene at $300 \mathrm{~nm}\left(\varepsilon_{300}=4.3 \mathrm{mM}^{-1} \mathrm{~cm}^{-1}\right)$ for $3 \mathrm{~min}$ at $30{ }^{\circ} \mathrm{C}$ (Kujawa et al. 2007). One unit of PDH activity was defined as the amount of enzyme required for the reduction of $2 \mu \mathrm{mol}$ of $\mathrm{Fc}^{+}$ion per minute.

\section{Molecular properties}

The protein concentration was determined by the method of Bradford using a prefabricated assay from Bio-Rad Laboratories (Hercules, CA, USA) and bovine serum albumin as the standard. SDS-PAGE was carried out using Mini-PROTEAN TGX precast gels with a denaturing gradient of $4-20 \%$. Protein bands were visualized by staining with Bio-Safe Coomassie; Dual Color Precision Plus Protein Standard was used for mass determination. All procedures were done according to the manufacturer's recommendations (Bio-Rad).

Enzymatic deglycosylation

Deglycosylation of a 15- $\mu \mathrm{g}$ sample of PDH was performed with peptide/ $N$-glycosidase $\mathrm{F}$, which cleaves the bond between $N$-acetyl-glucosamine. All procedures of the enzymatic deglycosylation of PDH with PNGaseF under denaturing conditions were done according to the manufacturer's recommendations.

Kinetic properties

Apparent kinetic constants for D-glucose, D-maltose, Larabinose, and lactose were measured using the standard ferrocenium assay as described earlier. Kinetic constants for the electron acceptors 1,4-benzoquinone, 2-chloro-1,4benzoquinone, and $\mathrm{Fc}^{+}$hexafluorophosphate were determined with $25 \mathrm{mM}$ glucose as electron donor. The $\mathrm{pH}$ dependence of PDH activity with different electron acceptors was determined with the following buffers: $100 \mathrm{mM}$ citrate $(\mathrm{pH}$ 2.5-6.0), $100 \mathrm{mM}$ phosphate ( $\mathrm{pH}$ 6.0-8.0), and $100 \mathrm{mM}$ borate $(\mathrm{pH}$ 8.0-9.0). All kinetic constants were calculated by nonlinear leastsquares regression, fitting the observed data to the Henri-Michaelis-Menten equation. Turnover numbers $\left(k_{\text {cat }}\right)$ and catalytic efficiencies $\left(k_{\text {cat }} / K_{\mathrm{m}}\right)$ were calculated using the molecular mass.

\section{Results}

Expression of pdh1 in E. coli

The E. coli expression plasmid pET21apdh1 was constructed by cloning the nucleotide sequence of mature PDH1 into the pET21a expression vector under control of the T7 promoter. Transformed E. coli BL21 (DE3) cultures carrying the plasmid were grown under different inducing conditions. Cultures were harvested $16 \mathrm{~h}$ after induction with 0.01 and $0.1 \mathrm{mM}$ IPTG as well as with $0.5 \%$ lactose, reaching an $\mathrm{OD}_{600}$ of roughly 11 . Harvested cells were resuspended in lysis buffer (three times the weight of the wet biomass of the sample) and disrupted using a French press. Disruption efficiencies were compared by measuring total protein concentration of the cleared lysate and varied between 1.1 and $2.0 \mathrm{mg} / \mathrm{mL}$ (corresponding to $4.4-8.0 \mathrm{mg}$ of protein per gram of cell paste). Crude extracts were tested for PDH activity using the standard enzyme assay. Unspecific background of a crude extract from an equally treated culture of E. coli BL21 (DE3) cells carrying the empty pET21a vector was subtracted from the measurements. No significant PDH activity was measured in any of the cultures. SDS-PAGE analysis of the total soluble proteins of the crude extract showed no band at the expected size (62 kDa) of PDH (data not shown). The insoluble part of the crude extract was tested for the possible existence of inclusion bodies of PDH on an SDSPAGE gel (data not shown). The majority of insoluble proteins were roughly the size of purified native $\mathrm{PDH}$.

\section{Expression of $p d h 1$ in $P$. pastoris}

Several constructs for extracellular expression of $p d h 1$ in $P$. pastoris were designed, all of them under control of

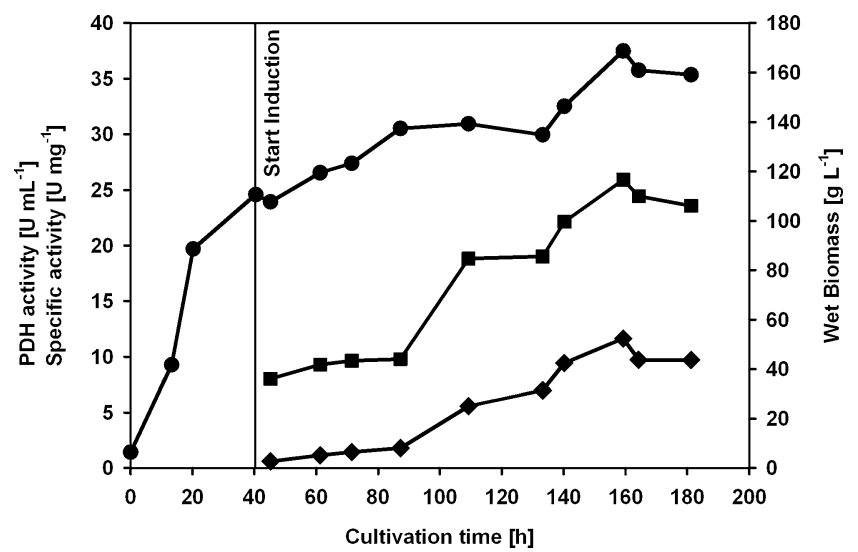

Fig. 1 Large-scale fermentation of $P$. pastoris n-PDH natCC11. Circles wet biomass, squares specific activity, diamonds volumetric activity. The measurements were done in duplicates and the error was always less than $5 \%$ 
Table 3 Purification of recombinant PDH1 from A. meleagris

\begin{tabular}{lllllll}
\hline & $\begin{array}{l}\text { Total activity } \\
(\mathrm{U})\end{array}$ & $\begin{array}{l}\text { Total protein } \\
(\mathrm{g})\end{array}$ & $\begin{array}{l}\text { Volume } \\
(\mathrm{L})\end{array}$ & $\begin{array}{l}\text { Specific activity } \\
\left(\mathrm{U} \mathrm{mg}^{-1}\right)\end{array}$ & $\begin{array}{l}\text { Purification } \\
(- \text { fold })\end{array}$ & $\begin{array}{l}\text { Activity yield } \\
(\%)\end{array}$ \\
\hline Culture supernatant & 517,000 & 22.6 & 51.5 & 22.9 & 1.0 & 100 \\
Phenyl Sepharose FF & $675,000^{\mathrm{a}}$ & 19 & 15.4 & 35.5 & 1.55 & 1.90 \\
DEAE Sepharose FF pool 1 & 48,100 & 1.1 & 0.98 & 43.7 & $130.6^{\mathrm{a}}$ \\
DEAE Sepharose FF pool 2 & 440,000 & 12.3 & 1 & 35.8 & 1.57 & 85.1 \\
\hline
\end{tabular}

${ }^{\text {a }} \mathrm{PDH}$ activity is higher when ammonium sulfate is present

${ }^{\mathrm{b}}$ Determination of kinetic constants was done with protein from this fraction

the inducible AOX1 promoter. For extracellular expression with the native signal sequence, the full-length open reading frames of $p d h 1$ and the gene sequence optimized for expression in P. pastoris (synpdh1) were cloned into the vector pPpT2 (Abad et al. 2010; Ruth et al. 2010). To test the efficiency of the native leader sequence, it was exchanged to a codon optimized $\alpha$-factor pre-pro leader peptide of $S$. cerevisiae by overlap extension PCR.

All resulting constructs were transformed into $P$. pastoris strain CBS 7435, cultivated in 96-well deep well plates, and screening for PDH activity (Table 2). On day 6 of the cultivation with approximately $72 \mathrm{~h}$ of induction by methanol, supernatants were tested for PDH activity. Constructs with the $\alpha$-factor leader sequence showed no significant PDH activity. In contrast, constructs with the native leader sequence resulted in P. pastoris transformants secreting active recombinant PDH1 (recPDH1). Overall, no significant difference in average activity could be observed when comparing the expression levels of all tested native with synthetic gene constructs. The standard deviation within one group of constructs was always approximately $10 \%$, which shows the uniformity of the 96well deep well plate screening and proves its suitability for high-throughput screening. To confirm the results from the first round of screening, a rescreening experiment with multiple parallel determinations was performed. The three synthetic gene transformants selected for the rescreen yielded an average volumetric PDH activity of around $0.31 \mathrm{UmL}^{-1}$. Three native gene transformants showed a slightly lower average PDH activity of $0.28 \mathrm{UmL}^{-1}$ but clone $\mathrm{n}$ PDH_natCC11 had a volumetric activity of $0.47 \mathrm{UmL}^{-1}$. This clone was selected for large-scale fermentation.

Scale up of recPDH1 production

P. pastoris clone n-PDH_natCC11, expressing extracellular rec $\mathrm{PDH} 1$, was cultivated on a $50-\mathrm{L}$ scale in a fed-batch fermentation for a total of $181 \mathrm{~h}$ (Fig. 1). The initial glycerol batch phase lasted for $13.5 \mathrm{~h}$ and its end, i.e., the exhaustion of the carbon source, was indicated by a sharp increase of the dissolved oxygen level. At this time point, a glycerol feed was started to further increase the cell density. After $40 \mathrm{~h}$ of cultivation, when the wet biomass had reached $111 \mathrm{gL}^{-1}$, the glycerol feed was stopped and induction with methanol started by continuously supplying this inducer. Levels of wet biomass reached $159 \mathrm{gL}^{-1}$ during the induction phase and the concentration of soluble protein in the culture supernatant increased from 70 to $440 \mathrm{mg} \mathrm{L} \mathrm{L}^{-1}$. Volumetric PDH activity in the culture supernatant reached a value of $10,040 \mathrm{UL}^{-1}$ at the time of harvest (corresponding to $\sim 230 \mathrm{mg}$ of recPDH1 per liter) with a specific activity of $22.9 \mathrm{Umg}^{-1}$ total protein.

\section{Purification of recombinant PDH1}

rec $\mathrm{PDH} 1$ was purified by a two-step chromatographic procedure as outlined in Table 3. Hydrophobic interaction chromatography was followed by an anion exchange chromatography step resulting in two pools containing active PDH. Pool 1 represented the center of the elution

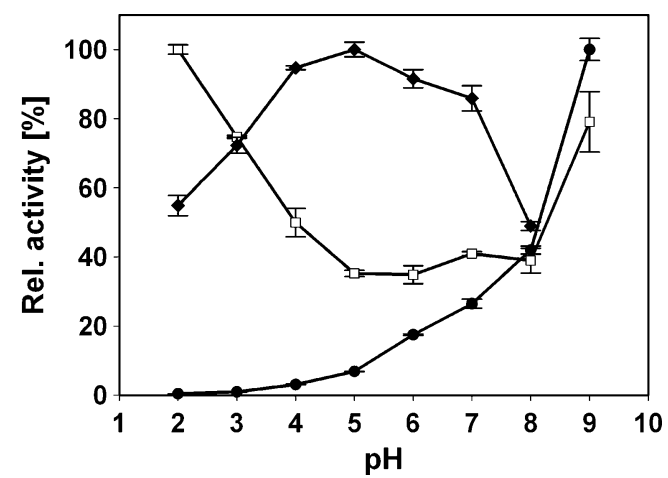

Fig. 2 Effect of $\mathrm{pH}$ on the activity of recombinant pyranose dehydrogenase using $25 \mathrm{mM}$ glucose as electron donor and different electron acceptors. Maximum activity measured for each electron acceptor corresponds to $100 \%$. Empty square 1,4-benzoquinone, filled circle ferrocenium hexafluorophosphate, filled diamond 2-chloro-1,4benzoquinone 
Table 4 Apparent kinetic constants of recPDH1 from A. meleagris for selected electron acceptor

\begin{tabular}{|c|c|c|c|c|c|c|c|}
\hline \multirow[t]{2}{*}{ Substrate } & \multirow[b]{2}{*}{$\mathrm{pH}$} & \multicolumn{3}{|c|}{ Recombinant PDH1 } & \multicolumn{3}{|c|}{ Native $A m \mathrm{PDH}^{\mathrm{a}}$} \\
\hline & & $k_{\text {cat }}\left(\mathrm{s}^{-1}\right)$ & $K_{m}(\mathrm{mM})$ & $k_{\text {cat }} / K_{m}\left(\mathrm{mM}^{-1} \mathrm{~s}^{-1}\right)$ & $k_{\text {cat }}\left(\mathrm{s}^{-1}\right)$ & $K_{m}(\mathrm{mM})$ & $k_{\mathrm{cat}} / K_{m}\left(\mathrm{mM}^{-1} \mathrm{~s}^{-1}\right)$ \\
\hline 1,4-Benzoquinone & 4.0 & $65.4 \pm 5.5$ & $1.38 \pm 0.28$ & 54.4 & $76.0 \pm 2.3^{\mathrm{b}}$ & $1.82 \pm 0.11^{\mathrm{b}}$ & $57.5^{\mathrm{b}}$ \\
\hline 2-Chloro-1,4-benzoquinone & 5.0 & $12.9 \pm 1.2$ & $0.62 \pm 0.11$ & 20.9 & $15.1 \pm 1.0$ & $0.55 \pm 0.11$ & 25.5 \\
\hline Ferrocenium hexafluorophosphate & 8.5 & $130 \pm 11$ & $0.16 \pm 0.04$ & 812 & $104 \pm 8$ & $0.13 \pm 0.03$ & 802 \\
\hline
\end{tabular}

Kinetic data were determined at $30{ }^{\circ} \mathrm{C}$ with $25 \mathrm{mM}$ D-glucose as the electron donor

${ }^{a}$ Data from Sygmund et al. (2008)

${ }^{\mathrm{b}}$ Measurements were done at $\mathrm{pH} 3.0$

peak and contained a homogenous enzyme preparation as judged by SDS-PAGE. Only $10 \%$ of the starting activity could be found in this amber-colored enzyme preparation with a specific activity of $43.6 \mathrm{Umg}^{-1}$ representing a 1.9fold purification from the culture supernatant. Protein from this pool was used for all further analyses. Since the emphasis of this purification procedure was put on high purification yields, aiming at possible subsequent applications of the enzyme, all other fractions containing PDH with relatively high specific activity were combined in pool 2 resulting in a recovery of $85 \%$ with a specific activity of $35.9 \mathrm{Umg}^{-1}$. In total, $13.4 \mathrm{~g}$ of more than $80 \%$ pure $r e c \mathrm{PDH} 1$ were obtained.

\section{Catalytic properties}

The $\mathrm{pH} /$ activity profiles of $\mathrm{rec} \mathrm{PDH} 1$ were measured for the electron acceptors 1,4-benzoquinone, $\mathrm{Fc}^{+}$hexafluorophosphate, and 2-chloro-1,4-benzoquinone, using glucose as electron donor (Fig. 2). recPDH1 showed a virtually identical $\mathrm{pH}$ behavior compared to the wildtype protein with benzoquinones having their $\mathrm{pH}$ optima in the acidic range whereas activity with $\mathrm{Fc}^{+}$continually increased with $\mathrm{pH}$ in the range of $\mathrm{pH} 3-9$. Apparent kinetic constants for these electron acceptor substrates were determined at those $\mathrm{pH}$ values that were previously used for wild-type PDH1 (Table 4). In addition, apparent kinetic constants were determined for selected sugar substrates and compared to those of the wild-type enzyme from A. meleagris (Table 5). Catalytic properties of rec $\mathrm{PDH} 1$ expressed in $P$. pastoris are almost identical to those of the wild-type enzyme (Sygmund et al. 2008).

\section{Molecular properties}

The molecular mass of recombinant PDH1 overexpressed in P. pastoris was determined to be $\sim 93 \mathrm{kDa}$ by SDS-PAGE (Fig. 3). Deglycoslylation under denaturing conditions using PNGase F reduced the mass of the protein to $64 \mathrm{kDa}$. This mass corresponds very well to the theoretical molecular mass of 61,967 Da based on the cDNA sequence of mature PDH1. Based on these results, the level of glycosylation of recPDH1 was calculated to be approximately $30 \%$.

\section{Discussion}

Production of PDH activity in its natural source, $A$. meleagris, is extremely tedious and time consuming as these cultivations have to be performed in resting shallow cultures for up to 6 weeks. Recently, the PDH1-encoding gene from A. meleagris was successfully expressed in

Table 5 Apparent kinetic constants of recPDH1 from A. meleagris for selected electron donor substrates

\begin{tabular}{|c|c|c|c|c|c|c|}
\hline \multirow[t]{2}{*}{ Substrate } & \multicolumn{3}{|c|}{ Recombinant PDH1 } & \multicolumn{3}{|c|}{ Native $A m \mathrm{PDH}^{\mathrm{a}}$} \\
\hline & $k_{\text {cat }}\left(\mathrm{s}^{-1}\right)$ & $K_{m}(\mathrm{mM})$ & $\mathrm{k}_{\mathrm{cat}} / K_{m}\left(\mathrm{mM}^{-1} \mathrm{~s}^{-1}\right)$ & $k_{\text {cat }}\left(\mathrm{s}^{-1}\right)$ & $K_{m}(\mathrm{mM})$ & $k_{\text {cat }} / K_{m}\left(\mathrm{mM}^{-1} \mathrm{~s}^{-1}\right)$ \\
\hline D-Glucose & $37.8 \pm 1.1$ & $0.69 \pm 0.09$ & 54.8 & $45.9 \pm 0.3$ & $0.82 \pm 0.03$ & 57.5 \\
\hline D-Galactose & $47.3 \pm 3.0$ & $1.07 \pm 0.13$ & 44.2 & $48.5 \pm 0.6$ & $1.05 \pm 0.05$ & 46.2 \\
\hline D-Xylose & $62.4 \pm 1.6$ & $1.92 \pm 0.14$ & 32.5 & $43.4 \pm 0.8$ & $1.93 \pm 0.17$ & 22.9 \\
\hline L-Arabinose & $34.7 \pm 1.6$ & $0.49 \pm 0.05$ & 70.8 & $37.2 \pm 0.6$ & $0.54 \pm 0.08$ & 62.1 \\
\hline Lactose & $41.0 \pm 8.1$ & $128 \pm 11.9$ & 0.32 & $39.6 \pm 0.8$ & $134 \pm 6.3$ & 0.29 \\
\hline
\end{tabular}

Kinetic data were determined at $30^{\circ} \mathrm{C}$ with $0.4 \mathrm{mM}$ ferricenium as the electron acceptor

${ }^{a}$ Data from Sygmund et al. (2008) 


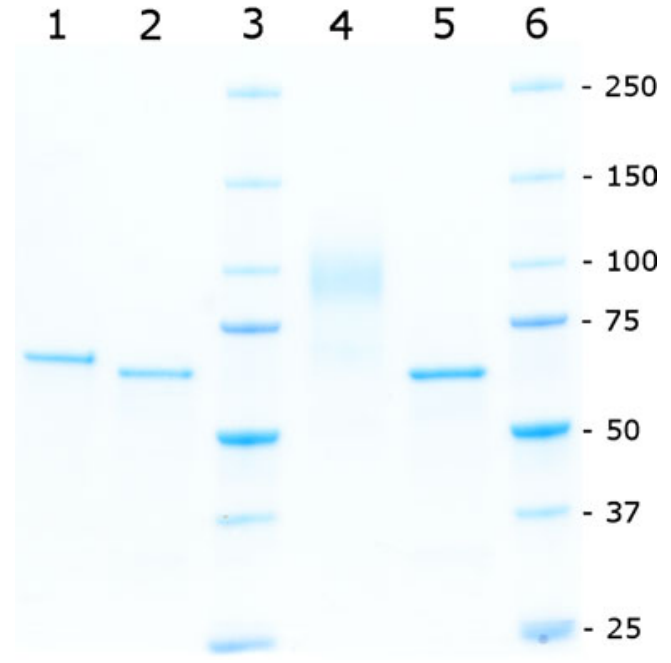

Fig. 3 SDS PAGE analysis of glycosylated and deglycosylated recombinant pyranose dehydrogenase expressed in $P$. pastoris and PDH1 purified from A. meleagris. 1 PDH1 from A. meleagris, 2 deglycosylated PDH1 from A. meleagris, 3 molecular mass marker (Precision Plus Protein Standards, Bio-Rad); 4 recPDH1 expressed in P. pastoris (purification pool 1), 5 deglycosylated rec $\mathrm{PDH} 1$ expressed in P. pastoris (purification pool 1); 6 molecular mass marker. The gel was stained with Coomassie blue

Aspergillus nidulans and Aspergillus niger. By using this approach, the final volumetric activity as well as the spacetime yield could be increased significantly with $A$. nidulans as expression host (Pisanelli et al. 2010) compared to production by the natural producer. However, timeconsuming transformation protocols and complicated genetic manipulation of Aspergillus spp. severely hamper any protein-engineering attempts. Therefore, other microbial expression systems that are better amenable to protein engineering approaches were tested for their ability to produce soluble and active PDH1. Both the prokaryotic host $E$. coli as well as the eukaryotic host $P$. pastoris were selected for expression studies.

The E. coli expression construct was designed for expression of PDH1 without $N$-terminal signal peptide. To reduce the possible formation of insoluble recombinant protein cultivation, temperature was lowered to $25{ }^{\circ} \mathrm{C}$ and the concentration of the inducer IPTG was varied. Still, PDH1 could only be found as insoluble protein fraction without any enzymatic activity under all tested conditions. One possible reason for the failure of expressing PDH in a prokaryotic system could be the need of glycosylation for correct protein folding as observed previously with other enzymes (Weis et al. 2007). On the other hand, there are examples where random mutagenesis was used to achieve functional expression of fungal proteins in $E$. coli (Sun et al. 2001). A similar strategy could possibly be used for successful expression of PDH1 in E. coli. Another key factor that seems to have major impact on PDH expression is the 25-amino acid long signal peptide. As reported earlier, expression levels of PDH1 in A. nidulans were much higher compared to the glaA signal sequence when its native signal sequence was used (Pisanelli et al. 2010). The same effect was observed in P. pastoris, and here it was even more pronounced. No PDH activity could be detected when using the $\alpha$-factor pre-pro signal sequence although identical constructs containing the native signal sequence showed relatively high expression levels. A similar effect, although less pronounced, was observed for the expression of other proteins in P. pastoris before (Colao et al. 2006). A possible reason could be the formation of secondary structures in the mRNA when the $\alpha$-factor is fused to the $p d h 1$ gene. However, analysis of the mRNA sequences of the four tested constructs using the program GeneBee (Brodsky et al. 1995) showed that constructs containing the $\alpha$-factor leader sequence neither have a lower calculated total free energy nor do they form stronger stem-loop structures compared to the sequences with the native signal sequence. The only significant difference with regard to stem-loop formation was between the synthetic gene and the noncodon-optimized sequence. This effect can be explained by the removal of regions capable of forming secondary structures during gene optimization.

A second possible explanation for the failure of expressing PDH1 with the $\alpha$-factor could be inefficient processing of this signal sequence in combination with the PDH protein sequence. Three proteolytic cleavage steps are necessary to fully process the $\alpha$-factor pre-pro leader sequence, and especially the efficiency of the last step can be influenced by the amino acids surrounding the cleavage site (Goda et al. 2000; Almeida et al. 2001). Isoleucine and tyrosine at position 2 and 4 of the mature protein can cause steric hindrance to the access of proteases, and thus affect processing of the protein by the Kex 2 or the Ste 13 protease. Another possible cause for inefficient processing of the protease cleavage sites could be glycosylation close to the $N$-terminus of the protein (Weiss et al. 1998). One possibility to solve this problem is to remove the Glu-Ala repeats by cloning the target gene flush with the Kex2 cleavage site. Another approach could be random mutagenesis in the entire secretion leader, which has been recently reported as a suitable strategy for the functional expression of a foreign laccase in yeast (Maté et al. 2010). Expression levels of both constructs with the native signal sequence in 96-well deep well cultivations were similar and in the range of $0.3 \mathrm{UmL}^{-1}$. Because of this relatively high and uniform expression level the, 96-well deep well cultivations can be used to screen for mutated enzymes produced by semirational design approaches. The use of the optimized synthetic gene did not increase the expression level; indeed, the highest volumetric activity was achieved by a transformant, n-PDH_natCC11, with native $p d h 1$ 
sequence. A large-scale laboratory fermentation of clone nPDH_natCC11 was performed to obtain large amounts of homogenous protein for protein crystallography and fast kinetic studies as well as to demonstrate the feasibility of industrial scale production of PDH for biotechnological applications. The 50 - $\mathrm{L}$ fermentation resulted in a volumetric activity of $10,040 \mathrm{UL}^{-1}$ or $1,330 \mathrm{UL}^{-1} \mathrm{~d}^{-1}$ in spacetime yield. This is a 28 -fold improvement of the space-time yield compared to the wild-type producer and a 1.6-fold improvement compared to A. nidulans expression yields (Pisanelli et al. 2010). The cultivation yielded $223 \mathrm{mg} \mathrm{L}^{-1}$ of recombinant protein, which corresponds to $52 \%$ of total extracellular protein. Because of the high specific activity (22.9 $\mathrm{U} \mathrm{mg}^{-1}$ ) of PDH in the culture supernatant, the previously established purification protocol (Sygmund et al. 2008) was changed to a two-step procedure with focus on fast high-yield purification. This represents another major advantage over expression in Aspergillus spp. where the presence of a large number of secreted proteins considerably reduces purification yields. The purification resulted in an apparently pure protein preparation with a specific activity of $43.7 \mathrm{Umg}^{-1}$ that was used for the subsequent biochemical characterization of the enzyme. To show that recombinant PDH1 can be purified in very high yields with this simple purification protocol for biotechnological applications, where a purity of the target protein of $80 \%$ is sufficient, other fractions with high specific activity were pooled resulting in a recovery of $85 \%$ of the initial activity and $12.3 \mathrm{~g}$ of PDH1. For applications where higher purity is required, the activity yield of $10.7 \%$ of pool 1 might be too low and then an additional purification step would be necessary. The specific activity of recombinant PDH1 obtained with $P$. pastoris is about $20 \%$ lower compared to wild-type PDH1. A possible reason for the reduced specific activity might be the higher degree of glycosylation of recPDH1 expressed in P. pastoris (30\% compared to $7 \%$ ), or inactive, not correctly folded protein that could not be separated from the active form. In contrast to $S$. cerevisiae, hyperglycosylation is not common for proteins expressed in P. pastoris. The high degree of glycosylation of PDH1 is a hint that the transit from the endoplasmic reticulum to the Golgi apparatus might be a bottleneck for the expression. The kinetic properties are essentially identical to those measured for the wild-type enzyme isolated from its natural source A. meleagris.

This study demonstrates the successful expression of $\mathrm{PDH}$ in the eukaryotic host organism P. pastoris and thus offers the possibility to easily produce and screen for genetically engineered PDH variants paving the way for future protein engineering. Additionally the feasibility of large-scale production of the enzyme using this expression system together with a simplified purification scheme for easy high-yield purification is shown.
Acknowledgments This work was supported by the Austrian Science Fund (FWF) (grant P22094 to CP) and IK is part of the doctoral program BioTop (Biomolecular Technology of Proteins), FWF W1224.

Open Access This article is distributed under the terms of the Creative Commons Attribution Noncommercial License which permits any noncommercial use, distribution, and reproduction in any medium, provided the original author(s) and source are credited.

\section{References}

Abad S, Nahalka J, Bergler G, Arnold SA, Speight R, Fotheringham I, Nidetzky B, Glieder A (2010) Stepwise engineering of a Pichia pastoris D-amino acid oxidase whole cell catalyst. Microb Cell Fact 9:24

Almeida MS, Cabral KS, De Medeiros LN, Valente AP, Almeida FCL, Kurtenbach E (2001) cDNA cloning and heterologous expression of functional cysteine-rich antifungal protein Psd1 in the yeast Pichia pastoris. Arch Biochem Biophys 395 (2):199-207

Ander P, Marzullo L (1997) Sugar oxidoreductases and veratryl alcohol oxidase as related to lignin degradation. J Biotechnol 53 (2-3):115-131

Barton SC, Gallaway J, Atanassov P (2004) Enzymatic biofuel cells for implantable and microscale devices. Chem Rev 104 (10):4867-4886

Brodsky LI, Ivanov VV, Kalaidzidis IL, Leontovich AM, Nikolaev VK, Feranchuk SI, Drachev VA (1995) GeneBee-NET: an Internet based server for biopolymer structure analysis. Biokhimiya 60(8):12211230

Bullen RA, Arnot TC, Lakeman JB, Walsh FC (2006) Biofuel cells and their development. Biosens Bioelectron 21(11):2015-2045

Colao M, Lupino S, Garzillo A, Buonocore V, Ruzzi M (2006) Heterologous expression of lccl gene from Trametes trogii in Pichia pastoris and characterization of the recombinant enzyme. Microb Cell Fact 5(1):31

Giffhorn F (2000) Fungal pyranose oxidases: occurrence, properties and biotechnical applications in carbohydrate chemistry. Appl Microbiol Biotechnol 54(6):727-740

Giffhorn F, Köpper S, Huwig A, Freimund S (2000) Rare sugars and sugar-based synthons by chemo-enzymatic synthesis. Enzyme Microb Technol 27(10):734-742

Goda S, Takano K, Yamagata Y, Katakura Y, Yutani K (2000) Effect of extra N-terminal residues on the stability and folding of human lysozyme expressed in Pichia pastoris. Protein Eng 13(4):299307

Kerem Z, Jensen KA, Hammel KE (1999) Biodegradative mechanism of the brown rot basidiomycete Gloeophyllum trabeum: evidence for an extracellular hydroquinone-driven fenton reaction. FEBS Lett 446(1):49-54

Kittl R, Sygmund C, Halada P, Volc J, Divne C, Haltrich D, Peterbauer CK (2008) Molecular cloning of three pyranose dehydrogenase-encoding genes from Agaricus meleagris and analysis of their expression by real-time RT-PCR. Curr Genet 53 (2):117-127

Kujawa M, Volc J, Halada P, Sedmera P, Divne C, Sygmund C, Leitner C, Peterbauer C, Haltrich D (2007) Properties of pyranose dehydrogenase purified from the litter-degrading fungus Agaricus xanthoderma. FEBS J 274(3):879-894

Lin-Cereghino J, Wong WW, Xiong S, Giang W, Luong LT, Vu J, Johnson SD, Lin-Cereghino GP (2005) Condensed protocol for competent cell preparation and transformation of the methylotrophic yeast Pichia pastoris. Biotechniques 38(1):44-48 
Lutz S (2010) Beyond directed evolution-semi-rational protein engineering and design. Curr Opin Biotechnol 21(6):734-743

Maté D, García-Burgos C, García-Ruiz E, Ballesteros AO, Camarero S, Alcalde M (2010) Laboratory evolution of high-redox potential laccases. Chem Biol 17(9):1030-1041

Morrison SC, Wood DA, Wood PM (1999) Characterization of a glucose 3-dehydrogenase from the cultivated mushroom (Agaricus bisporus). Appl Microbiol Biotechnol 51(1):58-64

Peterbauer CK, Volc J (2010) Pyranose dehydrogenases: biochemical features and perspectives of technological applications. Appl Microbiol Biotechnol 85(4):837-848

Pisanelli I, Kujawa M, Gschnitzer D, Spadiut O, Seiboth B, Peterbauer C (2010) Heterologous expression of an Agaricus meleagris pyranose dehydrogenase-encoding gene in Aspergillus spp. and characterization of the recombinant enzyme. Appl Microbiol Biotechnol 86(2):599-606

Reitz AB, Baxter EW (1990) Pyrrolidine and piperidine aminosugars from dicarbonyl sugars in one step. Concise synthesis of 1deoxynojirimycin. Tetrahedron Lett 31(47):6777-6780

Ruth C, Zuellig T, Mellitzer A, Weis R, Looser V, Kovar K, Glieder A (2010) Variable production windows for porcine trypsinogen employing synthetic inducible promoter variants in Pichia pastoris. Syst Synth Biol 4(3):181-191

Sun L, Petrounia IP, Yagasaki M, Bandara G, Arnold FH (2001) Expression and stabilization of galactose oxidase in Escherichia coli by directed evolution. Protein Eng 14(9):699-704

Sygmund C, Kittl R, Volc J, Halada P, Kubátová E, Haltrich D, Peterbauer CK (2008) Characterization of pyranose dehydrogenase from Agaricus meleagris and its application in the C-2 specific conversion of D-galactose. J Biotechnol 133(3):334342

Tasca F, Gorton L, Kujawa M, Patel I, Harreither W, Peterbauer CK, Ludwig R, Nöll G (2007) Increasing the coulombic efficiency of glucose biofuel cell anodes by combination of redox enzymes. Biosens Bioelectron 25(7):1710-1716

Volc J, Kubátová E, Wood DA, Daniel G (1997) Pyranose 2dehydrogenase, a novel sugar oxidoreductase from the basidiomycete fungus Agaricus bisporus. Arch Microbiol 167(2-3):119-125

Volc J, Kubátová E, Daniel G, Sedmera P, Haltrich D (2001) Screening of basidiomycete fungi for the quinone-dependent sugar $\mathrm{C}-2 / \mathrm{C}-3$ oxidoreductase, pyranose dehydrogenase, and properties of the enzyme from Macrolepiota rhacodes. Arch Microbiol 176(3):178-186

Weis R, Luiten R, Skranc W, Schwab H, Wubbolts M, Glieder A (2004) Reliable high-throughput screening with Pichia pastoris by limiting yeast cell death phenomena. FEMS Yeast Res 5(2):179-189

Weis R, Gaisberger R, Gruber K, Glieder A (2007) Serine scanninga tool to prove the consequences of $\mathrm{N}$-glycosylation of proteins. $\mathrm{J}$ Biotechnol 129(1):50-61

Weiss HM, Haase W, Michel H, Reiländer H (1998) Comparative biochemical and pharmacological characterization of the mouse 5HT5A 5-hydroxytryptamine receptor and the human- 32 adrenergic receptor produced in the methylotrophic yeast Pichia pastoris. Biochem J 330(3):1137-1147

Zafar MN, Tasca F, Boland S, Kujawa M, Patel I, Peterbauer CK, Leech D, Gorton L (2010) Wiring of pyranose dehydrogenase with osmium polymers of different redox potentials. Bioelectrochemistry 80(1):38-42 